\title{
PEMBUATAN EDIBLE FILM DARI PATI TEMU HITAM (Curcuma aeruginosa Roxb.) DENGAN PENAMBAHAN GLISEROL
}

\author{
Edible Film Preparation of Wild Ginger Starch (Curcuma aeruginosa Roxb.) With The \\ Addition of Glycerol
}

\author{
Mhd Iqbal Nusa1 ${ }^{1}$, Syakir Naim Siregar ${ }^{1}$ dan Laila Muzdalifah ${ }^{1}$ \\ ${ }^{1}$ Fakultas Pertanian Universitas Muhammadiyah Sumatera Utara \\ nusaiqbal@gmail.com
}

\begin{abstract}
The research objectives determine the effect of concentration Wild Ginger starch in suspension and adding glycerol on the edible film making of wild ginger starch. The Factorial Complete Randomized design was used with two factors. The first factor as treatments were the number of concentration Wild Ginger Starch in suspension ( $\mathrm{T}$ ) at four levels namely $\mathrm{T}_{1}=2 \%, \mathrm{~T}_{2}=4 \%, \mathrm{~T}_{3}=6 \%, \mathrm{~T}_{4}$ $=8 \%$. The second factor as treatment was the number of concentration glycerol adding $(\mathrm{G})$ at four levels namely $\mathrm{G}_{1}=20 \%, \mathrm{G}_{2}=30 \%, \mathrm{G}_{3}=40 \%, \mathrm{G}_{4}=50 \%$. The physical characteristics film were observed as Parameters namely The film thickness, percentage elongatios of film, and Water Vapor Transmission Rate (WVTR). The statistical analysis of the parameters indicated that increasing concentrations of wild ginger starch in suspensions very significantly difference effect $(\mathrm{P}<0,01)$ for film thickness, percentage elongation of film, and Water Vapor Transmission Rate (WVTR). The increasing of glycerol adding very significantly difference effect $(\mathrm{P}<0,01)$ for film thickness, and percentage elongation of film. Unlike the Water Vapor Transmission Rate (WVTR) was significantly difference effect $(P<0,05)$. Treatment interactions gave a very significantly different effect $(P<0,01)$ for the thickness, and percentage elongation of film. Unsignificantly difference effect $(P>0,05)$ for Water Vapor Transmission Rate (WVTR).
\end{abstract}

Keywords: Wild ginger starch, glycerol, WVTR, edible film.

\section{A. PENDAHULUAN}

Penggunaan kemasan sintetis yang umum digunakan selama ini menimbulkan masalah baru bagi kesehatan dan lingkungan hidup. Peningkatan kesadaran untuk menggunakan kemasan yang mudah terdegradasi dan aman bagi kesehatan dan tidak merusak lingkungan sangat diperlukan seperti edible film dan edible coating (McHugh dan Krochta 1994).

Edible film dan edible coating adalah lapisan tipis yang dibuat dari bahan yang dapat dimakan untuk pengemasan makanan (edible film) dan bahan pelapis makanan (edible coating) dengan cara membungkus, merendam, menyikat atau menyemprotkan bahan. Fungsinya sebagai penghambat (barrier) pada transfer massa uap air karena perbedaan kelembaban udara, gas oksigen, lemak dan zat terlarut dalam bahan makanan dan aditif untuk meningkatkan penanganan makanan (Krochta dkk. 1994). Penggunaan edible film antara lain sebagai pembungkus permen, sosis, buah, dan sup kering. Fungsi dan penampilan edible film bergantung pada sifat mekaniknya yang ditentukan oleh komposisi bahan, proses pembuatan dan metode aplikasinya (Yulianti dan Ginting, 2012).

Bahan dasar pembuatan edible film/coating adalah tiga kelompok bahan yaitu hidrokoloid (protein dan polisakarida), lipid (asam lemak dan wax) dan campuran (hidrokoloid dan lemak) (Krochta, 1994) Kelompok hidrokoloid yang ditambahkan berasal dari polisakarida adalah pati temu hitam. Pati merupakan salah suatu polimer yang dapat digunakan dalam pembuatan edible film. Dari berbagai jenis pati, pati temu hitam merupakan salah satu jenis pati yang mengandung komponen hidrokoloid yang dapat dimanfaatkan untuk membentuk matriks film. Pati temu hitam memiliki kandungan amilosa tinggi sekitar $24,45 \%$, dan kandungan amilopektinnya $75,54 \%$ sehingga berpotensi kapasitas pembentukan film dan menghasilkan film yang lebih kuat. (Purnama 2004). 
Hasil penelitian menunjukkan bahwa edible film yang terbuat dari bahan karbohidrat memiliki kelemahan struktur film yang bersifat rapuh. Plasticizer merupakan bahan yang sering ditambahkan dalam pembentukan edible film, karena memperbaiki karakteristik edible film menjadi elastis, fleksibel dan tidak mudah rapuh (Nemet et al., 2010). Gliserol sebagai salah satu bahan plasticizer yang sering digunakan dalam pembuatan edible film. Gliserol memiliki berat molekul rendah dan bersifat hidrofilik. Gliserol digunakan pada konsentrasi dan bahan yang berbeda akan menghasilkan karakteristik yang berbeda pula, (Khwaldia, 2004).

\section{B. METODOLOGI Bahan dan Alat}

Bahan penelitian yang digunakan terdiri bahan pati temu hitam, dan bahan kimia seperti gliserol, aquades.

Alat penelitian yang digunakan antara lain; Pisau, timbangan analitik, hot plate, magnetic stirer, ayakan 60 mesh, thermometer, pipet tetes, beaker glass, blender, kain saring, mortal dan alu, erlenmeyer, biuret, micrometer scrub, dan penggaris.

\section{Pelaksanaan Penelitian Pembuatan Pati Temu Hitam}

Pembuatan Pati Temu Hitam dilakukan dengan tahapan sebagai berikut; 1) pengupasan kulit dan pencucian umbi Temu hitam. 2) Pemarutan umbi, dan penyaringan untuk mendapatkan filtrat temu hitam. 3) pengendapan hasil saringan (fltrat) temu hitam selama 1 malam. 4) hasil endapan dikeringkan dengan suhu $60{ }^{\circ} \mathrm{C}$ selama 3 jam. Lalu dihancurkan dengan blender, kemudian ayak dengan ayakan 80 mesh sebagai fraksi pati temu hitam

\section{Pembuatan Edible Film Pati Temu Hitam}

Pembuatan edible film dari pati temu hitam dilakukan dengan tahapan sebagai berikut;1). Larutkan fraksi pati temu hitam kedalam aquadest sebanyak $20 \mathrm{ml}$ untuk mendapatkan konsentrasi pati dalam suspense sesuai dengan perlakuan yaitu 2\%, 4\%, 6\%, dan $8 \%$ (b/b). 2) Setiap suspensi yang dihasilkan, dilakukan penambahkan bahan plastilizer yaitu gliserol sebayak 20\%, $30 \%, 40 \%$, dan $50 \%$ (v/v), sesuai dengan perlakuan. Sehingga jumlah sampel percobaan adalah jumlah kombinasi perlakuan dengan 2(dua) ulangan. 3) Suspensi dengan penambahan gliserol diaduk sambil dipanaskan pada suhu $80{ }^{\circ} \mathrm{C}$ selama 30 menit. 4) suspensi kemudian didinginkan sambil dituangkan pada cetakan kaca persegi dengan ukuran yang sama 5). pengeringan (pengovenan) pada suhu $60^{\circ} \mathrm{C} 6$ ). pengambilan film dari cetakan setelah menunggu dingin utuk memudahkan pengambilan.

\section{Ketebalan Bahan Film Yang Dihasilkan (Mc.Hugh dan Krochta, 1994)}

Pengukuran ketebalan bahan film menggunakan micrometer scrub dengan ketelitian 0,01 mm. hasil pengukuran ketebalan film dari masing-masing sampel merupakan nilai rata-rata pengukuran pada lima titik pengukuran yaitu 4 titik sudut dan tengah terhadap hasil cetakan film bentuk persegi.

\section{Prosen Perpanjangan (Persentage of elongation) Bahan Film (ASTM, 1983)}

Angka prosen perpanjangan bahan film menunjukan angka perbandingan antara panjang film akibat adanya renggangan tarik sebelum putus terhadap panjang film sebelum dilakukan peregangan tarik yang dinyatakan dalam persen $(\%)$ atau

Elongasi $(\%)=\frac{\Delta \mathrm{L}}{\mathrm{L} 1} \times 100 \%$

Dimana ;

Elongasi $=$ Perpanjangan putus $(\%)$

$\Delta \mathrm{L}=$ Pertambahan panjang specimen $(\mathrm{mm})$

L1 = Panjang awal specimen (mm)

\section{Laju Transmisi Uap Air ( Xu, et al. 2005)}

Kemampuan bahan film dalam transmisi uap air ke dalam kemasan atau sebaliknya (gram/m2-jam), diukur secara gravimetri. Untuk menentukan besarnya jumlah uap air yang dapat menembus bahan kemasan film adalah mengukur perubahan berat sampel (gram) pada kondisi perbedaan kelembaban relatif untuk terjadi pergerakan uap air dalam periode waktu (jam) pada luas permukaan kemasan film $\left(\mathrm{m}^{2}\right)$.

\section{HASIL DAN PEMBAHASAN}

Hasil penelitian pengaruh penambahan konsentrasi pati temu hitam dan penambahan konsentrasi gliserol di dalam komposisi suspensi bahan pembuatan film terhadap besaran parameter yang diamati, dinyatakan 
sebagai angka rata-rata dilihat pada ke dua tabel berikut.

Tabel 1. Pengaruh Penambahan Pati Temu Hitam Terhadap Parameter Yang Diamati

\begin{tabular}{cccc}
\hline $\begin{array}{c}\text { Penambaha } \\
\text { n Pati Temu } \\
\text { Hitam }(\%)\end{array}$ & $\begin{array}{c}\text { Ketebala } \\
\text { n }(\mathrm{mm})\end{array}$ & $\begin{array}{c}\text { Perpanjang } \\
\text { an } \\
(\%)\end{array}$ & $\begin{array}{c}\text { Transmisi } \\
\text { Uap Air } \\
\left(\mathrm{gr} / \mathrm{m}^{2} / \mathrm{jam}\right)\end{array}$ \\
\hline T1 $=2 \%$ & 0.22 & 86,88 & 0,029 \\
$\mathrm{~T} 2=4 \%$ & 0.63 & 68,00 & 0,022 \\
$\mathrm{~T} 3=6 \%$ & 1.22 & 33,00 & 0,017 \\
$\mathrm{~T} 4=8 \%$ & 1.60 & 20,75 & 0,013 \\
\hline
\end{tabular}

Pada Tabel 1, dapat dilihat bahwa semakin tinggi penambahan pati temu hitam maka ketebalan akan semakin meningkat, sedangkan persen perpanjangan dan transmisi uap air menurun.

Tabel 2. Pengaruh Penambahan Gliserol Terhadap Parameter Yang Diamati

\begin{tabular}{cccc}
\hline $\begin{array}{c}\text { Penambah } \\
\text { an Gliserol } \\
(\mathrm{G})\end{array}$ & $\begin{array}{c}\text { Ketebalan } \\
(\mathrm{mm})\end{array}$ & $\begin{array}{c}\text { Perpanja } \\
\text { ngan } \\
(\%)\end{array}$ & $\begin{array}{c}\text { Transmisi } \\
\text { Uap Air } \\
(\mathrm{gr} / \mathrm{m} 2 / \\
\text { jam })\end{array}$ \\
\hline $\mathrm{G} 1=20 \%$ & 0.81 & 41,50 & 0,022 \\
$\mathrm{G} 2=30 \%$ & 0.86 & 51,75 & 0,021 \\
$\mathrm{G} 3=40 \%$ & 0.96 & 55,75 & 0,021 \\
$\mathrm{G} 4=50 \%$ & 1.05 & 59,62 & 0,019 \\
\hline
\end{tabular}

Pada Tabel 2 menunjukkan bahwa semakin tinggi konsentrasi penambahan gliserol dalam komposisi suspensi film, maka ketebalan dan persen perpanjangan film semakin meningkat sedangkan transmisi uap air bahan film akan menurun.

\section{Parameter Ketebalan Bahan Edible Film}

Berdasarkan analisa sidik ragam menunjukkan bahwa penambahan pati temu hitam memberikan pengaruh yang berbeda sangat nyata $(\mathrm{p}<0,01)$ terhadap ketebalan edible film. Tingkat perbedaan tersebut telah diuji dengan uji beda rata-rata yang dapat dilihat pada Tabel 3 berikut.

Tabel 3. Uji Beda Rata-Rata Perlakuan Pengaruh Penambahan Pati Temu Hitam Terhadap Ketebalan Edible Film

\begin{tabular}{|c|c|c|c|c|c|c|}
\hline \multirow[b]{2}{*}{ Jarak } & \multicolumn{2}{|c|}{ LSR } & \multirow{2}{*}{$\begin{array}{c}\text { Penambah } \\
\text { an Pati } \\
\text { Temu } \\
\text { Hitam(T) }\end{array}$} & \multirow[b]{2}{*}{$\begin{array}{c}\text { Rataan } \\
(\mathrm{mm})\end{array}$} & \multicolumn{2}{|c|}{ Notasi } \\
\hline & 0.05 & 0.01 & & & 0.05 & 0.01 \\
\hline - & - & - & $\mathrm{T} 1=2 \%$ & 0.22 & $\mathrm{~d}$ & $\mathrm{D}$ \\
\hline 2 & 0.033 & 0.045 & $\mathrm{~T} 2=4 \%$ & 0.63 & c & $\mathrm{C}$ \\
\hline 3 & 0.034 & 0.047 & $\mathrm{~T} 3=6 \%$ & 1.23 & b & B \\
\hline 4 & 0.035 & 0.048 & $\mathrm{~T} 4=8 \%$ & 1.60 & $\mathrm{a}$ & A \\
\hline
\end{tabular}

Keterangan : Huruf yang berbeda pada kolom notasi menunjukkan pengaruh yang berbeda nyata pada taraf $p<0,05$ dan berbeda sangat nyata pada taraf $p<0,01$.

Pada Tabel 3 di atas menunjukkan bahwa diantara perlakuan penambahan konsentrasi pati temu hitam berpengaruh berbeda sangat nyata terhadap ketebalan film yang dihasilkan. Angka ketebalan film tertinggi dapat dilihat pada perlakuan $\mathrm{T}_{4}=1.603 \mathrm{~mm}$ dan nilai terendah dapat dilihat pada perlakuan $\mathrm{T}_{1}=$ $0.224 \mathrm{~mm}$. Peningkatan konsentrasi pati temu hitam yang ditambahkan menyebabkan kenaikan jumlah total padatan dalam edible film sehingga terjadi peningkatan ketebalan edible film. Park, et al. (1996) menyatakan bahwa ketebalan film dipengaruhi oleh banyaknya total padatan dalam larutan suspensi bahan pembuatan film dan ketebalan cetakan. Hal ini terjadi karena penambahan jumlah pati yang semakin besar, akan meningkatkan polimer penyusun matriks film, total padatan edible film semakin besar sehingga film yang dihasilkan akan semakin tebal (Murdianto, 2005 ; Garcia et al, 2009).

Berdasarkan analisa sidik ragam dapat dilihat bahwa penambahan konsentrasi gliserol memberikan pengaruh yang berbeda sangat nyata $(\mathrm{p}<0,01)$ terhadap ketebalan edible film. Tingkat perbedaan tersebut telah di uji dengan uji beda rata-rata dan dapat dilihat pada Tabel 4 berikut.

Tabel 4. Hasil Uji Beda Rata-Rata Penambahan Gliserol Terhadap Ketebalan Edible Film

\begin{tabular}{|c|c|c|c|c|c|c|}
\hline \multirow{2}{*}{ Jarak } & \multicolumn{2}{|c|}{ LSR } & \multirow{2}{*}{$\begin{array}{l}\text { Penambah } \\
\text { an Gliserol } \\
\text { (G) }\end{array}$} & \multirow{2}{*}{$\begin{array}{c}\text { Rataan } \\
(\%)\end{array}$} & \multicolumn{2}{|c|}{ Notasi } \\
\hline & 0.05 & 0.01 & & & 0.05 & 0.01 \\
\hline & & & $\mathrm{G} 1=20 \%$ & 0.8 & $\mathrm{~d}$ & $\mathrm{D}$ \\
\hline 2 & 0.033 & 0.045 & $\mathrm{G} 2=30 \%$ & 0.86 & c & $\mathrm{C}$ \\
\hline 3 & 0.034 & 0.047 & $\mathrm{G} 3=40 \%$ & 0.96 & b & B \\
\hline 4 & 0.035 & 0.048 & $\mathrm{G} 4=50 \%$ & 1.05 & $\mathrm{a}$ & A \\
\hline
\end{tabular}

Keterangan : Huruf yang berbeda pada kolom notasi menunjukkan pengaruh yang berbeda nyata pada taraf $p<0,05$ dan berbeda sangat nyata pada taraf $p<0,01$.

Pada Tabel 4 di atas menunjukkan bahwa antara masing-masing perlakuan penambahan konsentrasi gliserol terhadap ketebalan film berpengaruh berbeda sangat nyata. Angka ketebalan film tertinggi diperoleh pada perlakuan $\mathrm{G}_{4}=1.050 \mathrm{~mm}$ dan nilai terendah diperoleh pada perlakuan $\mathrm{G}_{1}=0.806 \mathrm{~mm}$. Edible film yang terbuat dari karbohidrat memiliki kelemahan struktur film yang bersifat rapuh. Plasticizer merupakan bahan yang sering ditambahkan dalam pembentukan edible film akan memperbaiki karakteristik edible film 
menjadi elastis, fleksibel dan tidak mudah rapuh. Gliserol merupakan salah satu plasticizer yang sering digunakan dalam pembuatan edible film memiliki berat molekul rendah dan bersifat hidrofilik. Plasticizer yang ditambahkan dapat berikatan dengan pati membentuk polimer patiplasticizer. Ikatan antara pati dengan pati digantikan dengan ikatan antara pati-gliserol pati sehingga ketebalan meningkat seiring dengan bertambahnya konsentrasi gliserol dalam pasta film (Bourtoom et al.,2006).

Berdasarkan analisis sidik ragam diketahui bahwa interaksi penambahan pati temu hitam dan penambahan gliserol memberikan pengaruh berbeda nyata $(\mathrm{p}<0.01)$ terhadap ketebalan edible film yang dihasilkan. Hasil uji LSR pengaruh interaksi penambahan pati temu hitam dan penambahan gliserol terhadap ketebalan terlihat pada Tabel 5 berikut. Nilai rataan ketebalan bahan film yang dihasilkan tertinggi diperoleh pada pembuatan bahan film dengan penambahan konsentrasi pati temu hitam $8 \%\left(\mathrm{~T}_{4}\right)$ dan penambahan konsentrasi gliserol $50 \%$ (G4) yaitu $1.7700 \mathrm{~mm}$. Nilai rataan ketebalan film terendah diperoleh pada penambahan konsentrasi pati temu hitam $2 \%$ $\left(\mathrm{T}_{1}\right)$ dan penambahan konsentrasi gliserol 20 $\%\left(\mathrm{G}_{1}\right)$ yaitu $0.1650 \mathrm{~mm}$. Plasticizer merupakan bahan yang sering ditambahkan dalam pembentukan edible film akan memperbaiki karakteristik edible film menjadi elastis, fleksibel dan tidak mudah rapuh. Gliserol merupakan salah satu plasticizer yang sering digunakan dalam pembuatan edible film memiliki berat molekul rendah dan bersifat hidrofilik. Plasticizer yang ditambahkan dapat berikatan dengan pati membentuk polimer patiplasticizer. Ikatan antara pati dengan pati digantikan dengan ikatan antara pati-gliserol pati sehingga ketebalan meningkat seiring dengan bertambahnya konsentrasi gliserol dalam pasta film (Bourtoom et al., 2007).

Tabel 5. Uji LSR Pengaruh Interaksi Penambahan Pati Temu Hitam dan Penambahan Gliserol terhadap Ketebalan Edible film (mm)

\begin{tabular}{ccccccc}
\hline \multirow{2}{*}{ Jarak } & \multicolumn{2}{c}{ LSR } & \multirow{2}{*}{ Perlakuan Rataan } & \multicolumn{2}{c}{ Notasi } \\
\cline { 2 - 5 } & 0.05 & 0.01 & & & 0.05 & 0.01 \\
\hline- & - & - & T1G1 & 0.165 & $\mathrm{p}$ & NOP \\
2 & 0.0651 & 0.0896 & T1G2 & 0.200 & $\mathrm{o}$ & MNO \\
3 & 0.0683 & 0.0941 & T1G3 & 0.230 & $\mathrm{n}$ & $\mathrm{MN}$ \\
4 & 0.0700 & 0.0965 & T1G4 & 0.300 & $\mathrm{~m}$ & $\mathrm{M}$ \\
5 & 0.0716 & 0.0985 & T2G1 & 0.470 & $\mathrm{l}$ & $\mathrm{KL}$ \\
6 & 0.0724 & 0.0998 & T2G2 & 0.540 & $\mathrm{jk}$ & $\mathrm{K}$ \\
7 & 0.0731 & 0.1013 & T2G3 & 0.720 & $\mathrm{j}$ & $\mathrm{IJ}$ \\
\hline
\end{tabular}

\begin{tabular}{|c|c|c|c|c|c|c|}
\hline 8 & 0.0735 & 0.1024 & T2G4 & 0.780 & hi & I \\
\hline 9 & 0.0740 & 0.1032 & T3G1 & 1.140 & gh & GH \\
\hline 10 & 0.0744 & 0.1039 & T3G2 & 1.160 & g & FG \\
\hline 11 & 0.0744 & 0.1045 & T3G3 & 1.250 & $\mathrm{f}$ & $\mathrm{F}$ \\
\hline 12 & 0.0746 & 0.1050 & T3G4 & 1.350 & $\mathrm{e}$ & E \\
\hline 13 & 0.0746 & 0.1054 & $\mathrm{~T} 4 \mathrm{G} 1$ & 1.450 & $\mathrm{~d}$ & $\mathrm{D}$ \\
\hline 14 & 0.0748 & 0.1058 & T4G2 & 1.550 & c & BC \\
\hline 15 & 0.0748 & 0.1063 & T4G3 & 1.640 & $\mathrm{~b}$ & B \\
\hline 16 & 0.0750 & 0.1065 & T4G4 & 1.770 & $\mathrm{a}$ & A \\
\hline
\end{tabular}

\section{Parameter Prosentase Perpanjangan Bahan Film}

Dari analisa sidik ragam dapat dilihat bahwa penambahan konsentasi pati temu hitam memberikan pengaruh yang berbeda sangat nyata $(\mathrm{p}<0,01)$ terhadap persen perpanjangan edible film. Tingkat perbedaan tersebut telah diuji dengan uji beda rata-rata dan dapat dilihat pada Tabel 6. Berdasarkan uji beda rata-rata perlakuan menunjukkan bahwa masing-masing perlakuan berpengaruh berbeda sangat nyata antara satu dengan lainnya. Angka rata-rata tertinggi prosentase perpanjangan bahan film pada perlakuan penambahan konsentrasi pati dalam suspensi bahan film $\left(\mathrm{T}_{1}\right)=86,875 \%$, dan angka rerata terendah pada perlakuan penambahan konsentrasi pati dalam suspensi bahan film $\left(\mathrm{T}_{4}\right)=20,750 \%$.

Tabel 6. Hasil Uji Beda Rata-Rata Penambahan Pati Temu Hitam Terhadap Persen Perpanjangan Edible Film

\begin{tabular}{|c|c|c|c|c|c|c|}
\hline \multirow[b]{2}{*}{ Jarak } & \multicolumn{2}{|c|}{ LSR } & \multirow{2}{*}{$\begin{array}{c}\text { Penambahan } \\
\text { Pati Temu } \\
\text { Hitam (T) }\end{array}$} & \multirow{2}{*}{$\begin{array}{c}\text { Rataan } \\
(\%)\end{array}$} & \multicolumn{2}{|c|}{ Notasi } \\
\hline & 0.05 & 0.01 & & & 0.05 & 0.01 \\
\hline - & - & - & $\mathrm{T} 1=2 \%$ & 86,88 & $\mathrm{a}$ & A \\
\hline 2 & 2,947 & 4,057 & $\mathrm{~T} 2=4 \%$ & 68,00 & b & B \\
\hline 3 & 3,094 & 4,263 & $\mathrm{~T} 3=6 \%$ & 33,00 & $\mathrm{c}$ & $\mathrm{C}$ \\
\hline 4 & 3,173 & 4,371 & $\mathrm{~T} 4=8 \%$ & 20,75 & d & D \\
\hline
\end{tabular}

Semakin banyak pati yang ditambahkan ke dalam film plastik, maka elongasi akan menurun tapi kuat tarik akan meningkat. Penurunan elastisitas ini disebabkan oleh semakin menurunnya jarak ikatan antar molekulernya, karena titik jenuh telah terlampaui sehingga molekul-molekul pemplastis yang berlebih berada di dalam fase tersendiri di luar fase polimer dan akan menurunkan gaya intermolekul antar rantai, (Ramadhan, 2016). 
Hasil analisa sidik ragam dapat dilihat bahwa penambahan konsentrasi gliserol memberikan pengaruh yang berbeda sangat nyata $(\mathrm{p}<0,01)$ terhadap persen perpanjangan edible film. Tingkat perbedaan tersebut telah di uji dengan uji beda rata-rata dan dapat dilihat pada Tabel 7.

Tabel 7. Hasil Uji Beda Rata-Rata Penambahan Gliserol Terhadap Pesen Perpanjang Edible Film

\begin{tabular}{cccccccc}
\hline \multirow{2}{*}{ Jarak } & \multicolumn{2}{c}{ LSR } & Penambahan & Rataan & \multicolumn{2}{c}{ Notasi } \\
\cline { 2 - 5 } \cline { 6 - 8 } & 0.05 & 0.01 & Gliserol (G) & $(\%)$ & 0.05 & 0.01 \\
\hline- & - & - & G1 $=20 \%$ & 41,50 & d & D \\
2 & 2,947 & 4,057 & G2 $=30 \%$ & 51,75 & c & BC \\
3 & 3,094 & 4,263 & G3 $=40 \%$ & 55,75 & b & AB \\
4 & 3,173 & 4,371 & G4 $=50 \%$ & 59,62 & a & A \\
\hline
\end{tabular}

Keterangan : Huruf yang berbeda pada kolom notasi menunjukkan pengaruh yang berbeda nyata pada taraf $p<0,05$ dan berbeda sangat nyata pada taraf $p<0,01$.

Pada Tabel 7 di atas dapat dilihat antara setiap perlakuan menunjukkan perbedaan sangat nyata pengaruh penambahan konsentrasi gliserol terhadap prosentase perpanjangan bahan film. Angka rerata tertinggi diperoleh perlakuan $\mathrm{G}_{4}=59,625 \%$ dan nilai terendah diperoleh pada perlakuan $\mathrm{G}_{1}=41,500 \%$. Penambahan bahan plasticizer sangat penting untuk mengatasi film yang rapuh dan meningkatkan fleksibilitas (Brandenburg etal.,1993). Bahan film tanpa penambahan plasticizer akan menjadi sangat rapuh dan mudah pecah selama penanganan (Brandenburg,1993).Gliserol dapat berinteraksi dengan pati dengan cara membentuk ikatan pati-plasticizer dimana ikatan ini akan mengakibatkan peningkatan elastisitas dari suspensi keduanya. Penambahan plasticizer juga dapat menyebabkan turunnya gaya intermolekular sepanjang rantai polimer sehingga meningkatkan fleksibilitas (Khwaldia, 2004).

Analisa sidik ragam interaksi penambahan pati temu hitam dan penambahan gliserol memberikan pengaruh berbeda nyata $(\mathrm{p}<0.01)$ terhadap persen perpanjangan edible film yang dihasilkan. Hasil uji LSR pengaruh interaksi penambahan pati temu hitam dan penambahan gliserol terhadap persen perpanjangan terlihat pada Tabel 8 berikut.

Tabel 8. Uji LSR Efek Utama Pengaruh Interaksi Penambahan Pati Temu Hitam dan Penambahan Gliserol terhadap Persen Perpanjangan Edible film (\%)

\begin{tabular}{|c|c|c|c|c|c|c|}
\hline \multirow{2}{*}{ Jarak } & \multicolumn{2}{|c|}{ LSR } & \multirow{2}{*}{ Perlakuan } & \multirow{2}{*}{$\begin{array}{c}\text { Rataan } \\
(\%)\end{array}$} & \multicolumn{2}{|c|}{ Notasi } \\
\hline & 0.05 & 0.01 & & & 0.05 & 0.01 \\
\hline & & & T1G1 & 84,00 & $\mathrm{~d}$ & $\mathrm{ABCD}$ \\
\hline 2 & 5,8936 & 8,1135 & T1G2 & 86,50 & c & $\mathrm{ABC}$ \\
\hline 3 & 6,1883 & 8,5261 & T1G3 & 88,00 & $\mathrm{~b}$ & $\mathrm{AB}$ \\
\hline 4 & 6,3454 & 8,7422 & T1G4 & 89,00 & $\mathrm{a}$ & A \\
\hline 5 & 6,4829 & 8,9190 & T2G1 & 51,00 & $\mathrm{~h}$ & $\mathrm{H}$ \\
\hline 6 & 6,5615 & 9,0368 & T2G2 & 66,50 & g & G \\
\hline 7 & 6,6205 & 9,1744 & T2G3 & 76,00 & ef & DEF \\
\hline 8 & 6,6598 & 9,2726 & T2G4 & 78,50 & de & CDE \\
\hline 9 & 6,6990 & 9,3512 & T3G1 & 18,00 & no & LMNO \\
\hline 10 & 6,7383 & 9,4101 & T3G2 & 29,00 & $\mathrm{k}$ & K \\
\hline 11 & 6,7383 & 9,4690 & T3G3 & 39,00 & $\mathrm{j}$ & IJ \\
\hline 12 & 6,7580 & 9,5083 & T3G4 & 46,00 & hi & HI \\
\hline 13 & 6,7580 & 9,5476 & T4G1 & 13,00 & op & $\mathrm{OP}$ \\
\hline 14 & 6,7776 & 9,5869 & T4G2 & 25,00 & klm & KLM \\
\hline 15 & 6,7776 & 9,6262 & T4G3 & 20,00 & $\operatorname{lmn}$ & KLMN \\
\hline 16 & 6,7973 & 9,6458 & T4G4 & 25,00 & $\mathrm{kl}$ & KL \\
\hline
\end{tabular}

Angka rerata tertinggi prosentase perpanjangan film diperoleh pada perlakuan penambahan konsentrasi pati temu hitam $2 \%$ dan penambahan konsentrasi gliserol $50 \%$ yaitu 89,00 \%, dan angka rerata terendah diperoleh pada penambahan konsentrasi pati temu hitam $8 \%$ dan penambahan konsentrasi gliserol $20 \%$ yaitu 13,00 \%. Semakin tinggi penambahan pati temu hitam maka persen perpanjangan film akan menurun. Semangkin tinggi penambahan konsentasi gliserol maka persen perpanjangan film akan meningkat. Gugus hidroksil di sepanjang rantai gliserol merupakan penyebab terbentuknya ikatan hidrogen antara polimer pati dengan plasticizer yang menggantikan ikatan hidrogen antara polimer pati selama pembentukan biopolimer film (Bourtoom, 2007). Gliserol berfungsi secara efektif sebagai plasticizer berdasarkan kemampuan untuk mengurangi ikatan hidrogen internal dengan meningkatkan ruang kosong antar molekul, sehingga menurunkan kekakuan dan meningkatkan fleksibilitas film. Ruang kosong antar molekul tersebut diisi oleh plasticizer sehingga keberadaan plasticizer akan menurunkan tegangan interaksi antar molekul pati (Krochta, 1994). Hal ini sesuai dengan pernyataan Semakin banyak pati yang ditambahkan ke dalam film plastik, maka elongasi akan menurun tapi kuat tarik akan meningkat. Penurunan elastisitas ini disebabkan oleh semakin menurunnya jarak ikatan antar molekulernya, (Ramadhan, 2016). 


\section{Parameter Transmisi Uap Air bahan film}

Hasil analisa sidik ragam menunjukkan bahwa penambahan konsentrasi pati temu hitam memberikan pengaruh yang berbeda sangat nyata $(p<0,01)$ terhadap kemampuan transmisi uap air bahan film. Tingkat perbedaan tersebut telah diuji dengan uji beda rata-rata dan hasilnya dapat dilihat pada Tabel 9.

Tabel 9. Hasil Uji Beda Rata-Rata Penambahan Pati Temu Hitam Terhadap Transmisi Uap Air Edible Film

\begin{tabular}{|c|c|c|c|c|c|}
\hline \multirow[b]{2}{*}{ Jarak } & \multicolumn{2}{|c|}{ LSR } & \multirow{2}{*}{$\begin{array}{c}\text { Penambahan } \\
\text { Pati Temu } \\
\text { Hitam (\%) }\end{array}$} & \multirow{2}{*}{$\begin{array}{l}\text { Rataan } \\
\text { (gr/m² } \\
\text { /jam) }\end{array}$} & Notasi \\
\hline & 0.05 & 0.01 & & & $0.05 \quad 0.01$ \\
\hline - & - & - & $\mathrm{T} 1=2 \%$ & 0,029 & A \\
\hline 2 & 0,005 & 0,006 & $\mathrm{~T} 2=4 \%$ & 0,022 & B \\
\hline 3 & 0,005 & 0,007 & $\mathrm{~T} 3=6 \%$ & 0,017 & $\mathrm{BC}$ \\
\hline 4 & 0,005 & 0,007 & $\mathrm{~T} 4=8 \%$ & 0,013 & $\mathrm{~cd} \quad \mathrm{CD}$ \\
\hline
\end{tabular}

Pada tabel 9 diatas dapat dilihat bahwa perlakuan $\mathrm{T}_{1}$ berbeda sangat nyata dengan perlakuan $\mathrm{T}_{2}, \mathrm{~T}_{3}$, dan $\mathrm{T}_{4}$. Perlakuan $\mathrm{T}_{2}$ berbeda tidak nyata dengan $\mathrm{T}_{3}$ dan berbeda sangat nyata dengan $\mathrm{T}_{4}$. Perlakuan $\mathrm{T}_{3}$ berbeda tidak nyata dengan $\mathrm{T}_{4}$. Nilai tertinggi dapat dilihat pada perlakuan $\mathrm{T}_{1}=0,0299(\mathrm{gr} / \mathrm{m} 2 / \mathrm{jam}) \mathrm{dan}$ nilai terendah dapat dilihat pada perlakuan $\mathrm{T}_{4}=$ 0,0138 ( gr/m2/ jam). Pada penambahan fraksi pati ke dalam suspensi, granula pati bersifat higroskopis mudah menyerap air, kondisi kelembaban meningkat. Peningkatan diameter granula akan mendorong proses pembentukan jendalan pati, pati yang kandungan amilosanya tinggi akan lebih cepat dan banyak menyerap air, hasil jendalannya bervolume lebih mengembang dan kurang lekat. Sedangkan pati yang kadar amilosanya rendah lebih sedikit menyerap air dan jendalannya kurang mengembang tetapi lebih lengket (Haryadi dkk.,, 2002). Penggunaan edible film dibatasi oleh transmisi uap air yang tinggi karena sifat hidrofilik alaminya dan pada pembuatan edible film ditambahkan agen plasticizer untuk mendapatkan sifat lentur atau stretchable dari film. Efektifitas kontrol uap air merupakan komponen yang paling diutamakan dalam bahan makanan. Kadar air yang tinggi dapat menyebabkan makanan rusak dan berpengaruh terhadap masa simpan makanan (Ekawati, 2015).
Hasil analisa sidik ragam pengaruh penambahan konsentrasi gliserol dan interaksi penambahan pati temu hitam dengan penambahan gliserol memberikan pengaruh berbeda tidak nyata $(\mathrm{p}<0.05)$ terhadap kemampuan transmisi uap air edible film yang dihasilkan, sehingga pengujian selanjutnya tidak dilakukan.

\section{KESIMPULAN}

Hasil penelitian dan pembahasan Pembuatan Edible Film Pati Temu Hitam (Curcuma aeruginosa Roxb.) dengan penambahan Gliserol dapat disimpulkan sebagai berikut :

1. Penambahan pati temu hitam memberikan pengaruh yang berbeda sangat nyata pada taraf $p<0,01$ terhadap ketebalan, persen perpanjangan, dan transmisi uap air.

2. Penambahan gliserol memberikan pengaruh berbeda sangat nyata pada taraf $p<0,01$ terhadap ketebalan, persen perpanjangan, dan berbeda tidak nyata terhadap transmisi uap air.

3. Interaksi perlakuan konsentrasi pati temu hitam dengan penambahan gliserol memberikan pengaruh berbeda sangat nyata pada taraf $\mathrm{p}<0,01$ terhadap ketebalan dan persen perpanjangan film dan kemampuan transmisi uap air dari bahan film

\section{SARAN}

Suhu pemanasan, lama pengeringan, dan keseragam ukuran cetakan film mempengaruhi kualitas edible film yang dihasilkan

\section{DAFTAR PUSTAKA}

ASTM. 1983. Annual Book of ASTM Standards. American Society for Testing and Material. Philadelpia.

Bourtoom, T. 2007. Effect of Some Process Parameters on The Properties of Edible Film Prepared From Starch. Department of Material Product Technology,Songkhala.http://vishnu.sut.a c.th/iat/food_innovation/up/rice\%20star ch\%20film.doc.

Bourtoom, T.; Chinnan, M.S.; Jantawat, P.; Sanguandeekul, R. 2006 Effect of Select parameters on the Properties of Edible Film From Water-Soluble Fish Protein in 
Surimi Wash-Water. Departemen of Technology, Faculty of Science, 39, 405418.

Brandenburg, A.H., C.L. Weller and R.F. Testin. 1993. Edible Films and Coatings from Soy Protein. J. Food Sci. 58, 5 (1993) 10861089.

Ekawati, D. P. 2015. Kajian Pembuatan Edible Film Tapioka dengan Penambahan Surimi Ikan Lele Dumbo dan Ekstrak Kelopak Rosella pada Buah Tomat. [Skripsi] Fakultas Sains dan Teknologi. UIN Sunan Kalijaga. Yogyakarta.

García PG, SeGoVIa B, LóPez L, Jaren GM, GarrIdo F. 2009. Mechanism and polyphenols involved in the browning reaction of olives. Journal of Food Science 27(2):195-206.

Haryadi, Layuk, P., dan Djagal W.M. 2002. Karakteristik Komposit Film Edible Pektin Daging Buah Pala (Myristica Fragrans Houtt) dan Tapioka, Jurnal Teknologi dan Industri Pangan.

Khwaldia, K. Perez, C.Banon, S. Stephane, and, J. Hardy. 2004. Milk Proteins for Edible Films and Coatings. Critical Reviews in Food Science and Nutrition, 44:239-251.

Krochta, J.M., E.A. Baldwin, dan M.O. NisperosCarriedo. 1994. Edible Coating and Film to Improve Food Quality. Technomic Publishing Company. New York. NY.

Krochta, JM, Baldwin, E.A and NisperosCarriedo M.O., 1994. Edible Coatings and Films to Improve Food Quality. Technomis Publishing.Co.Inc. Lancester. Bosel.

Liu. Z. dan J. H Han. 2005. Film Forming Characteristics of Starches. J. Food Science. 70(1):E31-E36.

McHugh, T.H and J.M. Krochta. 1994. Water Vapor Permeability Properties of dible Whey Protein-lipid Emulsion Films. JAOCS 71:307-312.

Murdianto, W. 2005. Sifat Fisik dan Mekanik Edible film Ekstrak Daun Janggelan. J. Agrosains. 18 (3). Juli 2005.
Nemet, N.T., V.M. Soso and V.L. Lazic. 2010. Effect Of Glycerol Content and $p H$ Value of Film-forming Solution On The Functional Properties of Protein-based Edible Films. APTEFF, 41, 1-203.

Park, H.J., C.L. Weller, P.J. Vergano dan R.F. Testin. 1996. Factor Affecting Barrier and Mechanical Properties of Protein-edible, Degradable Films. New Orlean. L.A.

Purnama. 2004. Ekstraksi dan Karakterisasi Pati Temu Ireng. Balai Besar Penelitian dan Pengembangan Pascapanen Pertanian.

Ramadhan, S. 2016. Kajian Konsentrsi Tepung Ketan (Oryza Sativa Glutinous) Dan Gliserol Terhadap Karakteristik Edible Film Tepung Ketan. Teknologi Pangan, Fakultas Teknik Universitas Pasundan.

Xu, Y.X., K.M. Kim, M.A. Hanna, and D. Nag. 2005. Chitosan-starch composite film: preparation and characterization. Industrial Crops and Products 21:185192.

Yulianti, R. dan E. Ginting. 2012. Perbedaan Karakteristik Fisik Edible Film dari UmbiUmbian yang Dibuat dengan Penambahan Plasticizer. Penelitian Pertanian Tanaman Pangan. 31(2) ;131-136 